\title{
Analisis manajemen modal kerja pada bisnis kuliner di Indonesia
}

\author{
(studi pada UMKM di Desa Saptorenggo Kecamatan Pakis) \\ Sanditriyoga Hasmoro Widagdo, Ely Siswanto* \\ Universitas Negeri Malang, Jl. Semarang No. 5 Malang, Jawa Timur, Indonesia \\ *Penulis korespondensi, Surel: ely.siswanto.fe@um.ac.id
}

Paper received: 3-3-2021; revised: 24-3-2021; accepted: 28-3-2021

\begin{abstract}
Abstrak
Penelitian ini bertujuan untuk menganalisis manajemen modal kerja yang dilakukan oleh para pemilik dan pelaku UMKM bisnis kuliner di Desa Saptorenggo. Adapun fokus penelitian ini adalah bagaimana persepsi manajemen modal kerja yang ada pada bisnis kuliner di Desa Saptorenggo. Dari fokus tersebut peneliti membagi dengan tiga subfokus yakni, makna modal kerja, komponen modal kerja yang diterapkan, dan persepsi yang dibangun dalam pengelolaan modal kerja pada UMKM bisnis kuliner tersebut. Penelitian ini menggunakan jenis penelitian kualitatif deskriptif dengan metode fenomenologi hermeneutik. Data yang diperoleh peneliti secara langsung melalui wawancara, dokumentasi, dan observasi. Proses penelitian data yakni reduksi data, penyajian data, dan penarikan kesimpulan. Pengecekan keabsahan data pada penelitian ini menggunakan teknik triangulasi sumber. Hasil penelitian ini menunjukkan bahwa persepsi manajemen modal kerja menurut para pemilik dan pelaku UMKM bisnis kuliner di Desa Saptorenggo meliputi tiga poin. Pertama, makna modal kerja menurut para pemlik dan pelaku UMKM tersebut adalah uang, perilaku moral, dan keterampilan dalam usaha. Kedua, komponen yang diterapkan adalah kas, persediaan usaha, hutang lancar dengan mengesampingkan piutang usaha yang tidak relevan dalam menjalankan bisnis kuliner tersebut. Ketiga, persepsi yang dibangun oleh para pemilik dan pelaku UMKM adalah pengelolaan modal kerja yang berkelanjutan dengan tahap awal yakni, pengadaan modal dan pembelanjaan, dan selanjutnya di bagian tahap akhir ada pengorganisiran, pengoperasionalan, dan pengumpulan pendapatan atau kerugian usaha.
\end{abstract}

Kata kunci: manajemen modal kerja; persepsi pengelolaan modal kerja; UMKM bidang kuliner

\section{Pendahuluan}

Masa depan ekonomi bangsa bergantung bagaimana usaha ekonomi yang dijalankan oleh masyarakatnya. Dengan adanya UMKM (Usaha Mikro Kecil Menengah) yang hadir dalam masyarakat kelas bawah, tentu sangat mendukung suksesnya pemberdayaan masyarakat untuk menghadapi masa depan persaingan global yang sangat kompetitif. Untuk itu, UMKM di Indonesia perlu diperhatikan dan ditunjang keberlangsungannya oleh pemerintah lewat kebijakan-kebijakan yang menguntungkan pihak UMKM. Dari sisi masyarakat sendiri, menjadi produktif adalah kunci keberhasilan pendirian UMKM tersebut. Sosialisasi tentang potensi suatu wilayah perlu disampaikan oleh pejabat daerah terkait guna membangun taraf hidup masyarakat yang mandiri.

UMKM menurut definisi UU No. 20 Tahun 2008 ialah terdiri dari Usaha Mikro, Usaha Kecil, Usaha Menengah. Usaha Mikro adalah usaha produktif milik orang perorangan dan/atau badan usaha perorangan yang memenuhi kriteria Usaha Mikro sebagaimana diatur dalam Undang-Undang ini. Yang mempunyai kriteria aset maksimal 50 Juta dan omset maksimal 300 juta.

This work is licensed under a Creative Commons Attribution-ShareAlike 4.0 International License. 
Terkait dengan manajemen usahanya, pelaku bisnis bisa mengembangkan dari segi bagaimana pengelolaan modal kerjanya. Modal kerja adalah sumber dana perusahaan untuk melakukan aktivitas bisnisnya dalam kurun jangka pendek. Jadi ketika modal kerja atau aktiva lancar yang dimiliki perusahaan kurang memadai, maka perusahaan akan kesulitan melakukan setiap aktivitas bisnisnya, utamanya untuk pembelanjaan. Karena itu, para manajer keuangan perlu memperhatikan bagaimana sumber pendanaan dan sumber pembelanjaan modal kerja perusahaan terkait untuk pengelolaan yang efisien, sesuai tujuan perusahaan bisnis yang dimana untuk mensejahterakan stakeholder.

Untuk bisnis yang menyita perhatian khusus di Indonesia adalah bisnis yang bergerak di bidang kuliner lokal. Makanan tradisional atau kuliner lokal adalah jenis makanan yang berkaitan erat dengan suatu daerah dan diwariskan dari generasi ke generasi sebagai bagian dari tradisi, seperti dikutip dari Pieniak dalam Tyas (2017:3). Makanan lokal khas daerahdaerah di Indonesia sudah ada sejak lama dan masih bertahan hingga saat ini sehingga sangat dihargai sebagai warisan budaya. Resep yang digunakan juga sudah diturunkan dari generasi ke generasi, bahkan cara memasaknya juga masih melestarikan cara lama. Walaupun sudah ada modifikasi atau variasi, namun bahan utama dan prosedur memasaknya tidak berubah. Karena menjadi bagian dari suatu daerah, maka makanan-makanan tradisional ini sangat mudah ditemukan, bahkan menjadi ikon pariwisata di tempat tersebut, seperti pempek dari Palembang, Gudeg dari Yogyakarta, dan Selat Solo dari Solo.

UMKM di Desa Saptorenggo memiliki lokasi yang berdekatan dengan tetap pada wilayah Desa Saptorenggo. Dengan jarak dari pusat Kota Malang kurang lebih 12 KM, dan 2 KM dengan Bandar Udara Abdul Rachman Saleh, membuat lokasi desa sangat padat akan pengguna jalan dari maupun menuju ke Desa Saptorenggo. Lokasi Warung Lalapan Cak No berada di pusat desa (dekat dengan Balai Desa Saptorenggo), yang langsung berhimpitan dengan Warung Bakso \& Pangsit Cak Darto dan Warung Pecel \& Nasi Jagung Bu Nurikah. Sedangkan, Nasi Goreng Mbok Ndower berjarak kurang lebih 500 M dari ketiga UMKM lainnya tersebut. Volume kendaraan yang cukup padat membuat lokasi desa sangat mudah dijangkau untuk pengguna jalan, yang kebanyakan adalah pelanggan usaha UMKM tersebut.

Berjalannya bisnis UMKM disini tak lepas dari bagaimana metode penerapan pengelolaan sang pemilik. Para pemilik bisnis ini memiliki pengalaman membuka usahanya dengan rentang waktu kurang lebihnya 10 tahun. Terlepas dari itu, para pemilik tentunya memiliki pandangan berbeda-beda terkait bagaimana mengelola modal kerjanya. Dengan fenomena bagaimana usaha sang pemilik berjalan di waktu yang seperti itu, sangat menarik untuk diteliti karena berdasar pengalaman yang pemilik punya, perspektif-perspektif unik akan ditemukan dalam penelitian ini. Mulai dari bagaimana awal pembukaan bisnis, pola pikir yang dikembangkan, hingga pola pengelolaan yang konsisten, dinilai bisa menjadi kunci sukses para pemilik usaha bisnis kuliner ini.

Pada penelitian kualitatif ini memiliki batasan masalah. fokus penelitian yang dikemukakan ialah tentang "Bagaimana persepsi manajemen modal kerja pada UMKM bisnis kuliner di Indonesia”. Dengan fokus penelitian tersebut, peneliti akan membagi subfokus dengan: (1) Bagaimana makna modal kerja pada UMKM bisnis kuliner di Desa Saptorenggo? (2) Bagaimana komponen modal kerja yang diterapkan pada UMKM bisnis kuliner di Desa Saptorenggo? (3) Bagaimana pengelolaan modal kerja menurut persepsi yang dibentuk pada UMKM bisnis kuliner di Desa Saptorenggo 
Jurnal Ekonomi, Bisnis dan Pendidikan, 1(3), 2021, 283-296

\subsection{Modal Kerja}

Menurut Brigham dan Houston (2010:131) modal kerja adalah suatu investasi perusahaan di dalam aktiva jangka pendek seperti kas, sekuritas (surat-surat berharga), piutang dagang dan persediaan. Modal kerja yang dikelola dengan baik oleh manajer perusahaan akan mempengaruhi profitabilitas perusahaan. Sedangkan menurut Kasmir (2016:250) modal kerja adalah modal yang digunakan untuk melakukan kegiatan operasi perusahaan. Modal kerja juga dapat diartikan sebagai investasi yang ditanamkan dalam aktiva lancar atau aktiva jangka pendek seperti kas, surat-surat berharga, piutang, persediaan dan aktiva lancar lainnya.

Sutrisno (2012:39) menjelaskan bahwa pengertian modal kerja sebagai dana yang dibutuhkan perusahaan untuk memenuhi kebutuhan sehari-hari, seperti pembelian bahan baku, pembayaran upah buruh, membayar utang, dan pembayaran lainnya. Sedangkan menurut Sawir (2012:129) menyimpulkan pengertian modal kerja dengan pengertian bahwa modal kerja adalah keseluruhan aktiva lancar yang dimiliki perusahaan, atau dana yang harus tersedia untuk membiayai kegiatan operasi perusahaan.

Penggunaan modal kerja UMKM menurut Sugiono (2015), penggunaan modal kerja hanya sebatas untuk keperluan produksi, misalnya seperti pengeluaran untuk beban produksi seperti bahan baku produksi dan peralatan-peralatan serta tambahan biaya tenaga kerja (apabila sewaktu-waktu ada anggota tenaga kerja tidak hadir dalam proses produksi, sehingga UMKM tersebut harus menggunakan tenaga kerja lainnya untuk membantu proses produksi). Penggunaan modal kerja dapat mempengaruhi bentuk aktiva lancar perusahaan. Menurut Jumingan (2006:74) Penggunaan modal kerja akan menyebabkan perubahan bentuk atau aktiva bentuk perusahaan.

Sedangkan penggunaan modal kerja menurut Kasmir (2016:259) biasa dilakukan perusahaan untuk: (1) Pengeluaran untuk gaji, upah dan biaya operasi perusahaan lainnya. Maksudnya dari pengeluaran untuk gaji, upah dan biaya operasi perusahaan lainya, perusahaan mengeluarkan sejumlah uang untuk membayar gaji, upah dan biaya operasi perusahaan lainnya yang digunakan untuk menunjang penjualan. (2) Pengeluaran untuk membeli bahan baku atau barang dagangan. Maksud pengeluaran untuk membeli bahan baku atau barang dagangan adalah pada sejumlah bahan baku yang dibeli yang akan digunakan untuk proses produksi dan pembelian barang dagangan untuk di jual kembali. (3) Menutupi kerugian akibat penjualan surat berharga. Maksud menutupi kerugian akibat penjualan surat berharga adalah pada saat perusahaan menjual surat-surat berharga, namun mengalami kerugian. Hal ini akan mengurangi modal kerja dan segera ditutupi. (4) Pembentukan dana. Pembentukan dana merupakan pemisahan aktiva lancar untuk tujuan tertentu dalam jangka panjang, misalnya pembentukan dana pensiunan, dana ekspansi, atau dana pelunasaan obligasi. Pembentukan dana ini akan mengubah bentuk aktiva dari aktiva lancar menjadi aktiva tetap. (5) Pembelian aktiva tetap (tanah, bangunan, kendaraan, dan mesin). Pembelian aktiva tetap atau investasi jangka panjang seperti pembelian tanah, bangunan, kendaraan dan mesin. Pembelian ini akan mengakibatkan berkurangnya aktiva lancar dan timbulnya utang lancar. (6) Pembayaran utang jangka panjang. Maksudnya adalah adanya pembayaran utang jangka panjang yang sudah jatuh tempo seperti pelunasan obligasi, hipotek, dan utang jangka panjang. (7) Pembelian atau penarikan kembali saham yang beredar. Maksudnya adalah perusahaan menarik kembali saham-saham yang sudah beredar dengan alasan tertentu dengan cara 
membeli kembali, baik untuk sementara waktu maupun selamanya. (2) Pengambilan uang atau barang untuk kepentingan pribadi. Maksudnya adalah pemilik perusahaan mengambil barang atau uang yang digunakan untuk kepentingan pribadi, termasuk dalam hal ini adanya pengambilan keuntungan atau pembayaran dividen oleh perusahaan.

\subsection{Komponen Modal Kerja}

\subsubsection{Kas}

Kas merupakan alat pembayaran yang siap bebas digunakan untuk membiayai kegiatan operasional perusahaan, kas dapat berupa uang tunai, valuta asing dan bentuk-bentuk alat pembayaran lainnya (Mardiasmo, 2009). Menurut Harahap (2010:258) menyatakan bahwa kas adalah utang dan surat berharga yang dapat diuangkan setiap saat saat serta surat berharga lainnya yang sangat lancar.

Sedangkan menurut PSAK No.2 (IAI, 2013:22) kas terdiri dari saldo kas (cash on hand) dan rekening giro. Setara kas (cash equivalent) adalah investasi yang sifatnya sangat liquid, berjangka pendek dan dengan cepat dijadikan sebagai kas dalam jumlah tertentu tanpa menghadapi risiko perubahan nilai yang signifikan. Kas memiliki arti penting bagi perusahaan, mengingat semua operasional perusahaan berjalan jika adanya kas.

\subsubsection{Persediaan}

Menurut Atmaja (2008:405) persediaan merupakan salah satu komponen modal kerja yang tingkat likuiditasnya paling rendah dibandingkan dengan komponen modal kerja lainnya. Jumlah dan jenis persediaan sangat tergantung pada besar dan bentuk perusahaan. Sartono (2010:443) menjelaskan persediaan adalah salah satu jenis aktiva lancar yang jumlahnya cukup besar dalam suatu perusahaan.

\subsubsection{Piutang}

Piutang tercipta pada saat sebuah perusahaan melakukan penjualan hasil produksinya secara kredit, ini merupakan kebiasaan perusahaan untuk memberikan kelonggaran kepada pelanggan pada waktu melakukan penjualan (Jumingan, 2006:127). Menurut Warren.C.S, dkk (2015:404) menyatakan bahwa piutang mencakup seluruh uang yang diklaim terhadap entitas lain termasuk perorangan, perusahaan dan organisasi lain.

Hery (2013:181) menjelaskan piutang adalah sejumlah tagihan yang akan diterima oleh perusahaan umumnya dalam bentuk kas dari pihak lain. Dari definisi diatas peneliti menyimpulkan bahwa piutang merupakan sejumlah tagihan yang diklaim oleh perusahaan terhadap perusahaan lain.

\subsection{Arti Penting Modal Kerja}

Menurut Kasmir (2016:252) secara umum arti penting modal kerja bagi perusahaan terutama bagi kesehatan keuangan perusahaan, yaitu sebagai berikut: (1) Kegiatan seorang manajer keuangan lebih banyak dihabiskan di dalam kegiatan operasional perusahaan dari waktu ke waktu. Ini merupakan manajemen modal kerja. (2) Investasi dalam aktiva lancar cepat dan sering kali mengalami perubahan serta cenderung labil. Sedangkan aktiva lancar 
adalah modal kerja perusahaan, artinya perubahan tersebut akan berpengaruh terhadap modal kerja. Oleh karena itu, perlu mendapat perhatian yang sungguh-sungguh dari manajer keuangan. (3) Dalam praktiknya sering kali bahwa separuh dari total aktiva merupakan bagian dari aktiva lancar yang merupakan modal kerja perusahaan. Dengan kata lain, jumlah aktiva lancar sama atau lebih dari 50\% dari total aktiva. (4) Bagi perusahaan yang relatif kecil, fungsi modal kerja amat penting. Perusahaan kecil, relatif terbatas untuk memasuki pasar modal besar dan jangka panjang. Pendanaan perusahaan lebih mengandalkan pada utang jangka pendek, seperti utang dagang, utang bank satu tahun yang tentunya dapat mempengaruhi modal kerja. (5) Terdapat hubungan yang sangat erat antara pertumbuhan penjualan dengan kebutuhan modal kerja. Kenaikan penjualan berkaitan dengan tambahan, piutang, persediaan dan juga saldo kas. Demikian pula sebaliknya apabila terjadi penurunan penjualan, akan berpengaruh terhadap komponen dalam aktiva lancar.

Penelitian yang dilakukan Rofiq, Edward (2019) tentang kinerja manajemen modal kerja berdasarkan gender dan jenis usaha. Fokus pada penelitian ini ialah mendapatkan gambaran mengenai persepsi pengelolaan modal kerja dan kinerja perusahaan umkm troso dan mebel yang ada di Jepara. Penelitian ini menggunakan pendekatan kualitatif deskriptif. Objek penelitian yang diteliti ialah UMKM Troso dan mebel yang ada di Kota Jepara. Hasil penelitian ini menunjukkan bahwa manajemen modal kerja dan kinerja perusahaan berbasis gender dan jenis usaha secara umum sebagian besar perusahaan UMKM manajemen modal kerja-nya masih kurang baik sehingga perlu ditingkatkan lagi, hal ini juga terlihat dari peningkatan aset dan penjualan yang sebagian besar masih kurang. Untuk yang berbasis gender manajemen modal kerja meskipun sama-sama kurang baik, pemilik usaha pria pengelolaan modal kerjanya lebih baik dibandingkan pemilik usaha wanita. Sedangkan kinerja peningkatan aset dan penjualan perusahaan pemilik usaha pria hasilnya lebih baik dibandingkan pemilik usaha wanita. Manajemen modal kerja berbasis jenis usaha menunjukkan bahwa pada jenis usaha troso pengelolaannya lebih baik namun pada kinerja perusahaan justru jenis usaha mebel lebih baik. Untuk keseimbangan gender perlu dilihat lagi dalam hal akses jaringan dan sumberdaya yang dapat mendukung keberhasilan usaha pemilik usaha wanita.

Penelitian yang dilakukan Musinguzi (2016) tentang bagaimana pemilik bisnis UMKM di negara berkembang dalam mengelola modal kerjanya. Fokus pada penelitian ini ialah sistem, struktur, dan prosedur bagaimana pemilik bisnis UMKM mengelola modal kerja bisnisnya. Penelitian ini menggunakan pendekatan kualitatif deskriptif. Objek penelitian yang diteliti ialah 10 UMKM dari berbagai bidang dengan umur perusahaan paling tidak satu tahun yang ada di Negara Uganda. Hasil penelitian ini menunjukkan bahwa persepsi cara pandang pemilik bisnis tersebut dalam hal mengelola modal kerjanya memiliki perbedaan dibanding dengan pemahaman pengelolaan modal kerja umumnya. Pengelolaan yang dimaksud antara lain perencanaan yang dilakukan dengan intuisi, pencatatan, pengawasan, pengontrolan dalam mengelola kerjanya. Pencatatan-pencatatan yang dilakukan oleh pemilik dinilai tidak begitu penting bagi mereka, karena mereka semua fokus pada aliran arus kas yang ditunjukkan oleh para manajer.

Penelitian yang dilakukan Wardani (2019) tentang analisis manajemen modal kerja UMKM di Kota Mataram. Fokus pada penelitian ini ialah bagaimana keefektifan beberapa usaha dalam pengelolaan modal kerjanya. Penelitian ini menggunakan pendekatan kualitatif deskriptif. Objek penelitian yang diteliti ialah UMKM yang ada di Kota Mataram yang telah dipilih lewat variasi perbandingan pengeluaran dan pendapatan yang lebih dari 50\% dari data 
yang dikeluarkan oleh Dinas Koperasi Kota Mataram. Hasil penelitian ini menunjukkan bahwa pada tahun 2017, sebanyak 8 dari 13 perusahaan mengalami pertumbuhan modal kerja positif (naik) dari tahun 2016, sementara 5 perusahaan lainnya tidak mengalami perubahan. Sedangkan pada tahun 2018, sebanyak 5 dari 13 perusahaan memiliki pertumbuhan modal kerja positif (naik), Sedangkan perusahaan lainnya mengalami penurunan modal kerja. Efektifitas pengelolaan modal kerja pada UMKM di Kota Mataram pada tahun 2016 sampai 2018, masih belum efektif. untuk nilai rasio working capital turnover pada UMKM di Mataram tahun 2016 sampai 2018 masih rendah. Tingkat penjualan yang dapat dicapai masih rendah tidak sebanding dengan jumlah modal kerja (terutama jumlah persediaan barang) yang sangat besar. Kemampuan perusahaan yang rendah dalam menghasilkan penjualan menunjukkan tingkat perputaran persediaan barang sangat lambat.

Penelitian yang dilakukan Masocha, Dzomonda, (2016) tentang bagaimana hubungan keefektifan modal kerja terhadap prospek pertumbuhan usaha kecil dan menengah. Fokus pada penelitian ini ialah bagaimana siklus operasi usaha yang berisikan bagaimana pengaruh komponen komponen modal kerja perusahaan terhadap aliran modal kerjanya. Penelitian ini menggunakan pendekatan kuantitatif deskriptif. Objek penelitian yang diteliti ialah 50 UMKM dari berbagai bidang dengan klasifikasi; pegawai tetap berjumlah kurang dari 200, perputaran tiap tahunnya kurang dari R50 Juta (sekitar 48 Juta Rupiah), dan nilai aset tetap kotornya kurang dari R5 Juta (sekitar 4,8 Juta Rupiah) . Hasil penelitian ini menunjukkan bahwa hampir semua responden mengabaikan tata cara dan pencatatan dokumen penting untuk praktek manajemen modal kerja. Hal ini menunjukkan ketidakefektifan bagaimana pengelolaan modal kerjanya. Para pemilik bisnis kurang akan kemampuan dalam mengatur keuangan perusahaan. Hal ini akan menyebabkan tingkat kegagalan pada usaha UMKM di Kota Polokwane semakin tinggi.

Penelitian yang dilakukan Kusuma, Kohardinata, Herdinata (2017) tentang identifikasi faktor internal, faktor pendukung, faktor penghambat pada UMKM khususnya pada perusahaan skala menengah yang ada di Kota Surabaya yang mana mempengaruhi dalam keputusan pengelolaan modal kerja. Fokus pada penelitian ini ialah faktor-faktor yang mempengaruhi keputusan manajemen modal kerja. Penelitian ini menggunakan pendekatan kualitatif deskriptif. Objek penelitian yang diteliti ialah pengusaha skala menengah dengan kriteria kekayaan usaha bersih lebih besar dari dua ratus juta rupiah sampai dengan paling banyak sebesar sepuluh milyar rupiah tidak termasuk tanah dan bangunan tempat usaha dan memiliki karyawan lebih dari dua puluh orang sampai dengan kurang dari seratus orang. Hasil penelitian ini menunjukkan bahwa faktor internal yang mempengaruhi manajemen modal kerja yaitu penjualan, SOP (standard operating procedure) dan manajemen personalia. Sedangkan faktor eksternal yang mempengaruhi modal kerja yaitu konsumen dan pemasok. Faktor internal dan eksternal berpengaruh dalam mengelola manajemen modal kerja, perencanaan untuk ekspansi, pertumbuhan ekonomi, dan ketidakpastian pasar. Disisi lain, faktor pendukung yang mempengaruhi modal kerja yaitu sistem, kolektor, pemasok, sedangkan yang menjadi faktor penghambat yaitu sistem konsinyasi yang lunak dan tempo pembayaran. Faktor pendukung dan penghambat berpengaruh dalam pemanfaatan information technology (IT) dan keunggulan dalam kemampuan berinovasi. 


\section{Metode}

Penelitian dilakukan pada beberapa pemilik dan pelaku UMKM bisnis di bidang kuliner yang berada di Desa Saptorenggo Kecamatan Pakis Malang. Penelitian dilakukan selama kurun waktu 6 bulan, mulai dari April sampai September di tahun 2020.

Pertama, Bapak Suwarno (Cak No) dengan bisnis lalapan dan sambal khasnya. Lewat penjualan online juga, bisnis ini siap menghadapi era digital saat ini.

Kedua, Chairul Anwar (Mas Irul) dengan bisnis nasi gorengnya yang memiliki cabang hingga sepuluh unit yang tersebar malang raya bagian utara.

Ketiga, Ibu Nurikah dengan bisnis nasi pecel dan jagung yang dimilikinya. Usaha yang hanya buka pagi saja bisa menghasilkan keuntungan yang menjanjikan.

Keempat, Bapak Darto (Cak Darto) dengan usaha pangsit mie dan baksonya. Resep dari turun-temurun membuat bisnis ini sangat diminati kalangan luas.

Penelitian ini menggunakan metode kualitatif dengan pendekatan fenomenologi. Penelitian fenomenlogi peneliti adalah fenomenologi hermeneutik, dimana penelitian dilakukan lewat aspek-aspek subyektifitas dan obyektifitas dan penarikan kesimpulan. Data penelitian

didapat dari wawancara mendalam, observasi, dan dokumentasi. Proses penelitian data yakni pengumpulan data, reduksi data, penyajian data, dan penarikan kesimpulan. Pengecekan keabsahan data dilakukan dengan teknik triangulasi sumber saja, karena relevan dengan penelitian ini. ada 3 tahap penelitian yang dilakukan yakni tahap pra lapangan, tahap ke lapangan, dan terakhir tahap analisis data.

Tabel 1. Tabel Frekuensi Wawancara

\begin{tabular}{clll}
\hline No & Naman & $\begin{array}{l}\text { Jumlah } \\
\text { Pertemuan }\end{array}$ & $\begin{array}{l}\text { Durasi } \\
\text { Pertemuan }\end{array}$ \\
\hline 1. & $\begin{array}{l}\text { Bapak } \\
\text { Suwarno }\end{array}$ & 2 kali & 60 menit \\
2. & $\begin{array}{l}\text { Chairul } \\
\text { Anwar }\end{array}$ & 1 kali & 60 menit \\
3. & Bu Nurikah & 1 kali & 60 menit \\
4. & Bakap Darto & 1 kali & 45 menit \\
\hline
\end{tabular}

Dalam proses ini, peneliti berusaha mendeskripsikan gejala, sebagaimana gejala itu menampakkan dirinya pada pengamatan, maksudnya peneliti menggali data yang dimunculkan lewat pengalaman-pengalaman subjek maupun kondisi objek. Dikarenakan peneliti melihat fenomena UMKM bisnis kuliner di Desa Saptorenggo khususnya RW 04 ini memiliki potensi daya saing yang tinggi dari tahun ke tahun, terbukti dengan masih eksisnya bisnis-bisnis tersebut hingga saat ini. Didukung dari pengalaman subjek - subjek penelitian tersebut, penelitian ini akan menggambarkan lebih jelas, bagaimana fenomena usaha kuliner bisnis yang sukses dan menguntungkan. Dengan menggunakan penelitian kualitatif ini, Peneliti berharap agar bisa memaparkan sudut pandang yang dipahami oleh para pemilik bisnis UMKM ini untuk menjadi bahan utama dari penjelasan deskriptif dari peneliti. 


\section{Hasil dan Pembahasan}

\subsection{Makna Modal Kerja}

Dari temuan penelitian tersebut, peneliti menyimpulkan bahwa pemahaman yang dimiliki oleh para pemilik maupun pelaku UMKM sangat variatif. Penjelasan dari narasumber cukup terbilang sulit untuk dipahami dikarenakan perbedaan maksud dan arti yang dipahami oleh para narasumber tersebut. Karena mempunyai latar belakang pendidikan di bawah sekolah lanjutan tingkatan atas (SMA/SMK sederajat), narasumber menyampaikan arti yang dipahami akan modal kerja cukup menarik dan dijelaskan secara sederhana. Modal kerja menurut para pemilik maupun pelaku UMKM adalah, uang, perilaku moral, dan keterampilan yang mendukung usaha dari jam awal operasional sampai tutup per harinya.

Dari segi materil, para pelaku UMKM berbanding sama untuk mendapatkan uang belanja awal usaha, baik uang sendiri maupun menggunakan pinjaman dari bank, dimana para pelaku tersebut membayarkan cicilan tiap bulannya. Dari segi moril, narasumber menjelaskan bahwa perilaku budi pekerti seperti jujur, ulet, tekun, dan rajin adalah modal awal di samping modal materil, dimana modal materil yang peneliti sebut adalah modal kerja menurut kaidah akuntansi yang berlaku.

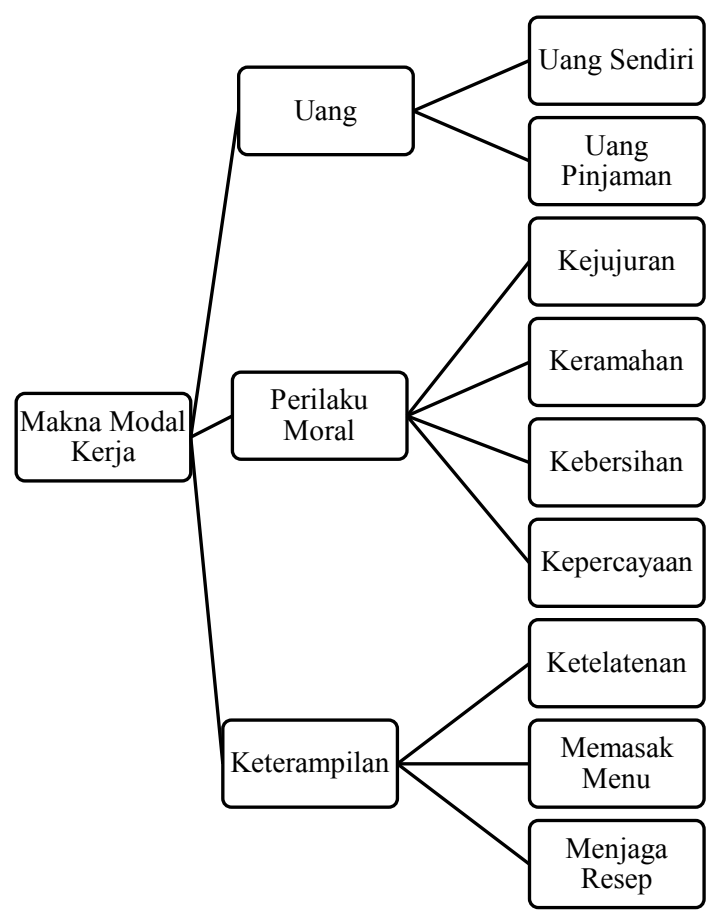

Gambar 2. Bagan Penjelasan Makna Modal Kerja Bagi Pengusaha dan Pelaku UMKM di Desa Saptorenggo Pakis 


\subsection{Komponen Modal Kerja}

Komponen berjalan dengan lancar walaupun sedikit ada ketimpangan pada proses berjalannya usaha. Ketimpangan tersebut bisa dijelaskan pada narasumber yang tidak mempunyai hutang pajak diiringi dengan omzet rata-rata per hari lebih dari Rp 1.000.000,-. Jika dikalkulasikan dalam sebulan kurang lebih sekitar Rp 30.000.000,- per bulan, yang dimana usaha tersebut seharusnya membayar pajak. Sebagian besar kas didapat dari hasil penjualan hari kemarin usaha.

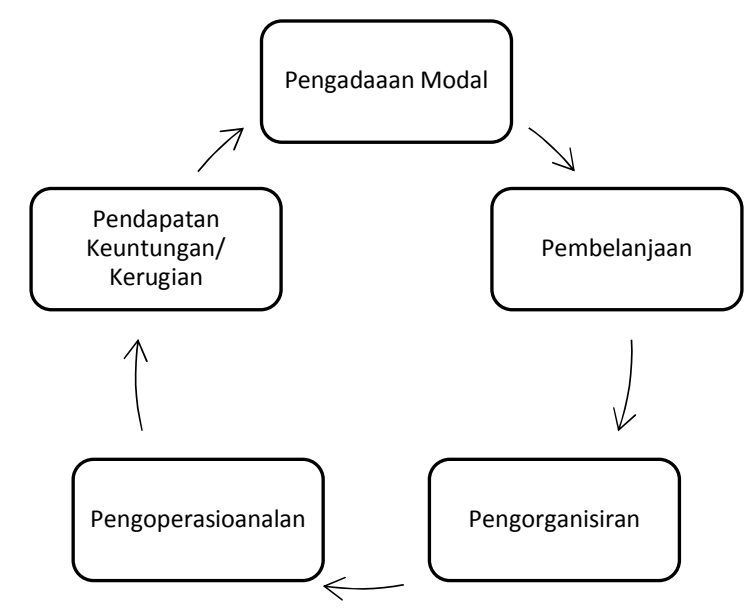

Gambar 3. Bagan Penjelasan Bagaimana Komponen Modal Kerja yang Diterapkan Pada UMKM Bisnis Kuliner Desa Saptorenggo Kecamatan Pakis

Komponen yang pertama adalah kas yang didapat dari menu utama, yaitu berupa makanan, dan menu pelengkap, yaitu berupa minuman, krupuk, dll. Komponen persediaan terdiri dari jumlah pembelian, pengorganisiran, teknik penjagaan kualitas, dan kebutuhan yang mempengaruhi. Komponen ketiga yaitu hutang lancar, yaitu berupa pengupahan pegawai, angsuran pinjaman dari bank, angsuran sewa bangunan, serta pengenaan pajak usaha.

Untuk pajak usaha, seperti sudah dijelaskan di awal, pengenaannya masih belum diterapkan pada UMKM meskipun sudah ada pengajuan yang seperti dilakukan oleh narasumber ke-empat yang datang langsung ke kantor pajak terkait. Bebas pajak yang dikenakan pada UMKM tersebut dikarenakan kurang dari klasifikasi pengenaan pajak terhadap UMKM pada kebijakan pemerintah. Maka dari itu para pemilik belum wajib untuk membayarkan pajak.

Untuk pengelolaan persediaan semua ditangani oleh pemilik maupun kepala cabang. Untuk penjualan piutang semua usaha tidak menerima, karena penjualan piutang sangat sulit untuk diterapkan pada bisnis kuliner, umumnya UMKM, menurut semua narasumber.

\subsection{Pengelolaan Modal Kerja Berkelanjutan}

Dari awal pembelanjaan hingga mendapat keuntungan, semua usaha menjalankan prosesnya secara teratur dan sesuai kebutuhan usahanya. dengan menggunakan metode yang 
mereka gunakan, usaha ini masih eksis hingga saat ini. Mulai dari menjaga resep, memberdayakan semua pegawai, hingga mengelola keuangan dengan cara bijak.

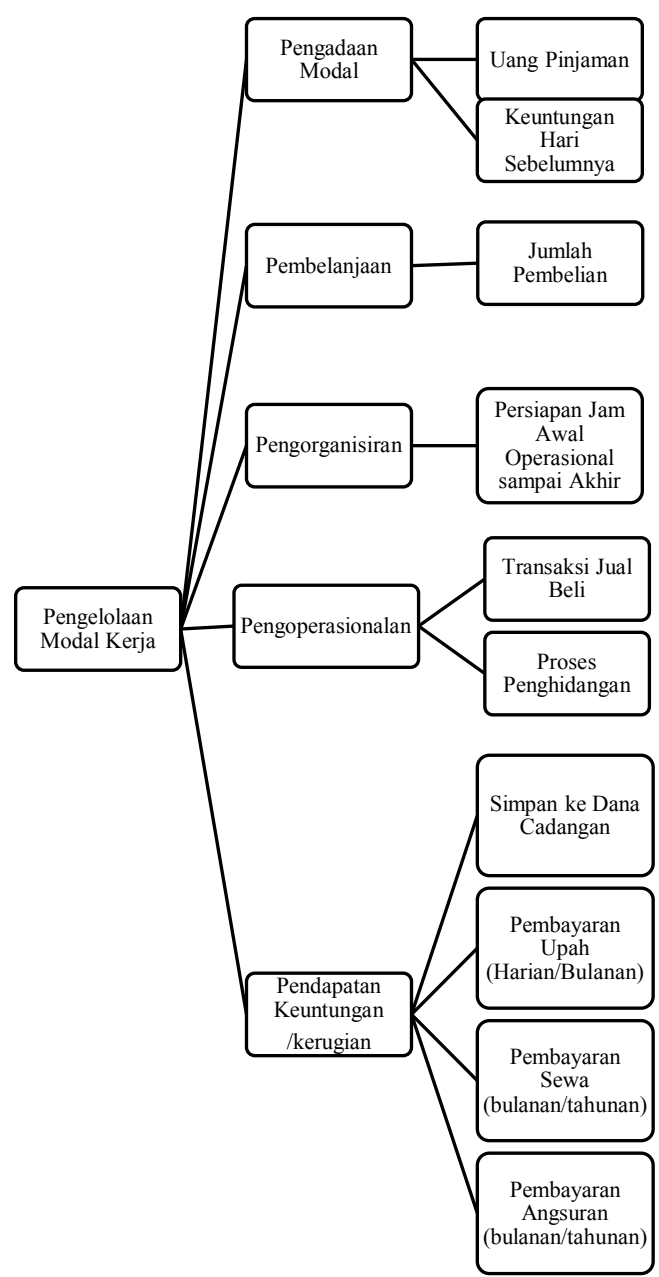

Gambar 4. Pola Pengelolaan Modal Kerja Pada UMKM di Desa Saptorenggo Pakis

Dari semua usaha, komponen-komponen aktiva lancar (kas dan setara kas) dan hutang lancar (upah pegawai, dan hutang bank) dikelola secara teratur dan sesuai prosedur dari pemilik, yang dimana prosedur dari pemilik didapatkan dari pengalaman selama menjalankan usahanya. jumlah kas yang tiap hari terus bertambah berasal dari bagaimana pemilik maupun pelaku UMKM dalam mengatur ritme dalam pengelolaan komponen-komponen tersebut. 


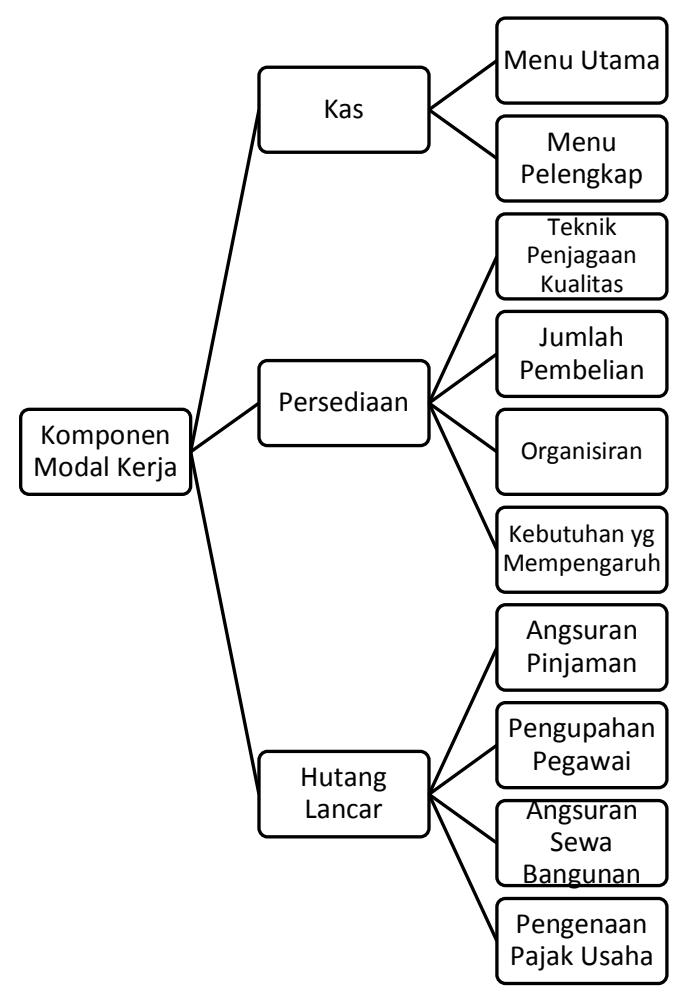

\section{Gambar 5. Bagan Penjelasan Bagaimana Pengelolaan Modal Kerja Menurut Persepsi yang Dibangun oleh Para Pelaku UMKM}

\section{Simpulan}

Penelitian ini bertujuan untuk menganalisis manajemen modal kerja yang dilakukan oleh pemilik dan pelaku UMKM bisnis kuliner di Desa Saptorenggo yang terdiri dari makna modal kerja, komponen modal kerja yang diterapkan, dan pengelolaan modal kerja menurut persepsi yang mereka bangun. Berdasarkan hasil temuan dan pembahasan, maka dapat ditarik kesimpulan sebagai berikut.

\subsection{Makna Modal Kerja}

Makna modal kerja menurut para pemilik dan pelaku UMKM bisnis kuliner adalah terdiri dari uang, perilaku moral, dan keterampilan. yang mendukung usaha dari jam awal operasional sampai tutup per harinya.

Uang digunakan untuk memulai sebuah usaha dan modal tersebut akan digunakan untuk kegiatan produksi sehari-hari. Uang yang ada pada UMKM bisnis kuliner di Desa Saptorenggo merupakan modal ekonomi usaha. Uang pada UMKM bisnis kuliner ini berasal dari uang sendiri dan pinjaman. Uang sendiri, berasal dari keuntungan hari sebelumnya. Sedangkan uang pinjaman berasal dari pinjaman bank yang angsurannya dibayar sebulan sekali

Selain uang, terdapat perilaku moral yang menunjang bagaimana modal kerja pada usaha-usaha ini berjalan. Perilaku moral yang diterapkan antara lain, kejujuran, keramahan, dan kebersihan. Ketika perusahaan menjalankan beberapa modal sosial tersebut, kepercayaan 
akan dibangun oleh suatu usaha atas dasar karakteristik masing-masing individu tersebut. Utamanya dari modal sosial yang dijalankan pada usahanya yang berawal dari diri para pengusaha dan pelaku UMKM bisnis kuliner tersebut.

Sebagai pelengkap, keterampilan adalah modal yang tidak kalah utama dengan sebelumnya. Dari sini keterampilan dapat menjadikan semangat dan bisa menjadikan inspirasi bagi pelaku UMKM, khususnya pegawai. Keterampilan usaha meliputi ketelatenan membagi bahan persediaan, penjagaan resep masakan, dan keterampilan memasak. para pengusaha dan pelaku UMKM disini berusaha menjaga resep maupun cita rasa yang dihasilkan agar bisa menjadi ciri khas usaha yang kompetitif di lingkup bisnis

\subsection{Komponen Modal Kerja}

Komponen yang diterapkan pada UMKM bisnis kuliner di Desa Saptorenggo meliputi kas, persediaan, dan hutang lancar. Semua usaha disini tidak menerapkan piutang pada penjualannya, dikarenakan tidak efektif untuk usaha yang berskala mikro seperti ini, dan juga pembelian langsung tatap muka (kecuali Warung Lalapan Cak No).

Dalam penerapannya, kas usaha berasal dari aktivitas operasional sehari-hari dari penjualan usaha untuk digunakan sebagai pembelian maupun pembiayaan usaha setiap harinya. Penjualan usaha terdiri dari menu utama yaitu menu makanan dan menu pelengkap seperti minuman, cemilan, dan kerupuk. Perencanaan kas sendiri juga dilakukan secara nonformal, karena produksi dilakukan setiap hari sehingga para pemilik dan pelaku UMKM bisnis kuliner ini sudah hafal apa saja yang dibutuhkan tanpa adanya laporan tertulis Tidak ada target penjualan dalam usaha ini. hal ini yang menyebabkan pengendalian untuk pengadaan kas sedikit tidak terarah dengan baik. Tujuan usaha semata-mata agar mendapat keuntungan dari penjualan tiap harinya yang belum menentu juga. Pelaksanaan terhadap pengadaan kasnya dilakukan oleh pemilik dan pelaku UMKM bisnis kuliner hampir setiap hari. Selain itu pengelolaan persediaan yang ada pada UMKM bisnis kuliner disini meliputi jumlah pembelian, pengorganisasian, kebutuhan yang mempengaruhi, dan teknik penjagaan kualitas. persediaan bahan baku yang diperoleh pemilik, berasal dari penjual sayur atau daging langganannya.

Persediaan di setiap usaha ada dua yaitu persediaan bahan baku dan persediaan barang dagang. Persediaan bahan baku bisa dibilang bahan mentah yang belum dimasak, sedangkan barang dagang adalah bahan setengah masak atau jadi Pengorganisasian terhadap persediaan yang diterapkan oleh pemilik dan pelaku UMKM bisnis kuliner ini merupakan persediaan barang dagang yaitu dengan melakukan penyetokkan bahan setengah jadi agar siap untuk dimasak Pengendalian terhadap persediaan bahan baku yang dilakukan oleh pemilik dan pelaku UMKM bisnis kuliner ini adalah dengan menjaga kualitas bahan persediaan, utamanya persediaan bahan mentah. Pelaksanaan persediaan disini bergantung pada apa saja kebutuhan yang mempengaruhi, selain kebutuhan untuk bisnis. Sisanya, para pemilik dan pelaku UMKM ini membeli bahan baku untuk stok sesuai dengan apa yang dibutuhkan atau sesuai dengan uang yang ada untuk melakukan pembelian bahan baku. Sedangkan pelaksanaan terhadap persediaan barang dagang yang dilakukan di tempat jualan yaitu memasak menu bahan setengah jadi sesuai pesanan setiap hari untuk memenuhi permintaan konsumen.

Komponen pengurang adalah hutang lancar yang dimiliki usaha. Hutang lancar pada usaha UMKM bisnis kuliner di Desa Saptorenggo meliputi pengupahan pegawai, angsuran pinjaman, dan angsuran sewa bangunan. Untuk pengeluaran pada hutang lancar ini para 
pemilik dan pelaku UMKM berfokus pada pengendalian, dikarenakan jika pembayaran dilakukan tidak sesuai dengan tenggat waktu, prosedur, maupun perjanjian, maka akan mengganggu biaya operasional sehari-hari bisnis. Pengendalian terhadap hutang yang dilakukan oleh para pemilik dan pelaku UMKM bisnis di Desa Saptorenggo Pakis adalah dengan secara rutin per bulan sekali melunasi hutang angsuran kepada bank. Ini dilakukan untuk menghindari denda yang makin menumpuk ketika pembayaran hutang dilakukan terlambat maupun terlewat. Untuk pembayaran angsuran sewa bangunan dilakukan setahun sekali, kecuali bisnis kuliner yang memakai lahan atau rumah sendiri. Pembayaran upah pegawai ada yang melakukan per bulan dan ada juga yang harian, dikarenakan adanya pegawai harian lepas yang ikut membantu usaha tersebut

\subsection{Pengelolaan Modal Kerja}

Dalam pengelolaan modal kerja dalam persepsi para pemilik dan pelaku UMKM bisnis kuliner di Desa Saptorenggo dilakukan secara berkelanjutan. Dengan proses awal sebelum di lapangan yaitu bagian pengadaan modal yang berasal dari uang pinjaman bank ditambah keuntungan dari hari sebelumnya dan melakukan pembelanjaan untuk bahan persediaan dengan menentukan jumlah pembeliannya.

Untuk tahap selanjutnya yang ada di lapangan (tempat usaha), sebelum pengoperasionalan usaha, dilakukan pengorganisasisan bahan persediaan, dengan memulai dari menyiapkan bahan setengah jadi sampai persiapan untuk pesanan yang bawa pulang (bungkus). Setelah itu transaksi akan ada terus selama operasional usaha dibuka. Disini para pemilik memantau sembari mengisi persediaan bahan setengah jadi agar siap dimasak kapanpun di waktu yang dibutuhkan. Untuk kepala cabang sendiri, ikut memasak dalam operasional usaha dan melakukan persiapan jika ada telepon dari cabang lainnya yang membutuhkan pasokan persediaan.

Setelah operasional usaha selesai, para pemilik dan pelaku UMKM memberikan upah sesuai kontrak kerja yang diberikan, harian maupun bulanan (kalkulasi per harinya). Setelah pendapatan bersih dikurangi pembayaran tersebut, lalu kesemuanya disimpan ke dana cadangan masing-masing. Dana cadangan ini berguna untuk menambah pembelanjaan untuk hari besok dan ditabung untuk pembayaran angsuran bank maupun sewa bangunan.

Saran yang disampaikan peneliti adalah: (1) Bagi Pengusaha dan Pelaku UMKM Bisnis Kuliner Desa Saptorenggo yaitu untuk manajemen modal kerja yang dilakukan oleh para pemilik dan pelaku UMKM bisnis kuliner di Desa Saptorenggo sudah mendekati efisien lewat pengelolaan yang berkelanjutan. Namun, akan sangat bagus ketika pengelolaannya ditambah dengan keefektifan dengan cara membuat laporan keuangan tiap bulannya. Hal ini dimaksudkan agar usaha-usaha berkembang seperti ini bisa menjadikan nilai jual usaha semakin tinggi. Pencatatan keuangan secara terperinci dalam pembukuannya ini diharapkan akan mempermudah proses pengecekkan bagaimana uang masuk dan keluarnya. Untuk pemasaran usaha boleh dicoba juga dilakukan secara online, meskipun butuh waktu untuk merubah metode penjualan. Dari yang semula tatap muka saja, diharapkan kedepannya dapat bersaing dengan usaha sejenis lainnya di era digital saat ini. (2) Bagi Pemerintah yaitu diharapkan agar pemerintah selalu mengedepankan pemberdayaan masyarakat lewat penumbuhan UMKM yang sudah mulai banyak tumbuh di era globalisasi ini dengan menetapkan kebijakan-kebijakan tentang kredit modal yang menguntungkan UMKM. Hal ini 
mengingat bahwa bisnis UMKM seperti ini adalah penggerak ekonomi negara walaupun negara sedang dilanda krisis ekonomi. Pengklasififkasian akan wajib pajak UMKM perlu direvisi lagi agar pendapatan negara ini didapat merata dari sektor tersebut. Dari sini pemerintah juga, lewat pemerintahan desa pun bisa membuat festival-festival UMKM untuk menjadi ajang memperkenalkan UMKM yang kompetitif dalam lingkup bisnis usaha kuliner ini. (3) Bagi Peneliti Selanjutnya yaitu sebaiknya menambah objek penelitian, sehingga data yang diperoleh lebih bervariasi serta bisa dijadikan objek pembanding antara yang satu dengan lainnya sehingga dapat memperluas topik yang diteliti Dan dapat mengembangkan penelitian untuk dijadikan studi komparatif tentang usaha kuliner dengan sektor usaha lainnya misalnya, sehingga menjadikan topik penelitian tentang daya saing masyarakat lebih tinggi dan kompetitif kedepannya.

\section{Daftar Rujukan}

Atmaja, L. S. (2008). Teori dan Praktek Manajemen Keuangan. Yogyakarta: Andi

Brigham, E.F. \& Houston, J.F. (2010). Dasar-Dasar Manajemen Keuangan. Edisi 11. Jakarta: Salemba Empat.

Harahap, S. S., (2010). Analisis Kritis Atas Laporan Keuangan. Jakarta: Rajawali Persada.

Herdinata, C., Kusuma, M., \& Kohardinata, C. (2017). Analisis Manajemen Modal Kerja pada Usaha Skala Menengah di Surabaya.

Hery, (2013). Auditing (Pemeriksaan Akuntansi I) Cetakan Pertama, Jakarta: CAPS (Center of Academic Publishing Service).

Indonesia, I. A. (2009). Standar akuntansi keuangan entitas tanpa akuntabilitas publik.

Jumingan, (2006). Analisis Laporan Keuangan. Jakarta: Bumi Aksara.

Kasmir, (2016). Analisis Laporan Keuangan. Jakarta: Raja Grafindo Persada.

Kusmayadi, I., Suryawati, B.N., Wardani, L. (2019). Analisis Manajemen Modal Kerja UMKM di Kota Mataram. Jurnal Kompetitif: Media Informasi Ekonomi Pembangunan, Manajemen dan Akuntansi, (Online), 6 (1): 64-71, (http://e-journal.unizar.ac.id), diakses 26 September 2019

Mardiasmo, (2009), Akuntabilitas Sektor Publik. Yogyakarta: Andi.

Masocha, R., Dzomonda, O. (2016). The Mediating Role of Effective Working Capital Management on The Growth Prospects of Small and Medium Enterprises in Polokwane Municipality. SAAPAM Limpopo Chapter $5^{\text {th }}$ Annual Conference Proceedings, (Online), (http://www.researchgate.net), diakses 24 September 2019

Musinguzi, D. (2013). How Do Small Business Owners Manage Working Capital in An Emerging Economy? Qualitative Research in Accounting \& Management, (Online), 10 (2): 127-143, (http://www.emeraldinsight.com), diakses 25 September 2019

Rofiq, E., Edward, M.Y. (2019). Kinerja Manajemen Modal Kerja Berdasarkan Gender dan Jenis Usaha. Jurnal Sosio e-kons., (Online), 11 (2): 165-173, (https://journal.lppmunindra.ac.id), diakses 26 September 2019.

Sartono, R. A., (2010). Manajemen Keuangan (Teori dan Aplikasi). Yogyakarta: BPFE.

Sawir, A. (2015). Analisis Kinerja Keuangan dan Perencanaan Keuangan Perusahan. Jakarta: Gramedia Pustaka Utama.

Sugiyono. (2015). Metode Penelitian Kombinasi (Mix Methods). Bandung: Alfabeta 28, 1-12.

Sutrisno, (2012). Manajemen Keuangan (Teori, Konsep dan Aplikasi). Yogyakarta: Ekonisia.

Tyas, A.S.P., (2017). Identifikasi Kuliner Lokal Dalam Pembelajaran Bahasa Inggris. Jurnal Pariwisata Terapan, (Online) 1 (1): 38-51, (https://jurnal.ugm.ac.id/jpt). Dikases 25 September 2019

Undang-Undang Republik Indonesia No 20 Tahun 2008 tentang UMKM, (Online), (www.bi.go.id), diakses tanggal 24 September 2019.

Warren, C. S., dkk. 2015. Pengantar Akuntansi. Jakarta: Salemba Empat. 